UDC 629.424.1-82:004.318

\author{
I. V. ZHUKOVYTSKYY ${ }^{1 *}$, I. A. KLIUSHNYK ${ }^{2 *}$ \\ ${ }^{1 *}$ Dep. «Electronic Computing Machines», Dnipropetrovsk National University of Railway Transport named \\ after Academician V. Lazaryan, Lazaryan St., 2, Dnipro, Ukraine, 49010, tel. +38 (056) 37315 89, e-mail ivzhuk@mail.ru, \\ ORCID 0000-0002-3491-5976 \\ $2^{*}$ Dep. «Electronic Computing Machines», Dnipropetrovsk National University of Railway Transport named \\ after Academician V. Lazaryan, Lazaryan St., 2, Dnipro, Ukraine, 49010, tel. +38 (056) 37315 89, e-mail klugran@i.ua, \\ ORCID 0000-0001-9939-0755
}

\title{
USE OF MICROCONTROLLER FOR MEASURING SHAFT SPEED OF DIESEL LOCOMOTIVE HYDRAULIC TRANSMISSION
}

Purpose. The article considers the process of development and improvement of tachometer data collectors for the data-measuring diesel locomotive hydraulic transmission test system, which will give the possibility of obtaining the source data to conduct further studies of the technical condition of diesel locomotive hydraulic transmission. It is supposed to provide a solution to the problem of development and improvement of tachometer data measuring tools of the previously created data-measuring diesel locomotive hydraulic transmission test system, starting out from the possibility of modification of the existing locomotive hydraulic transmission test-bench at the Dnepropetrovsk Diesel Locomotive Repair Plant «Promteplovoz». Methodology. The researchers proposed in the work a method of modifying the existing tachometer sensor of the automated microprocessor system for the locomotive hydraulic transmission test-bench in the conditions of a diesel locomotive repair plant. It is applicable by substantiating the choice of the required tachometer sensor measuring method, as well as by using the necessary hardware and software to accomplish the goal with the ability to integrate into the data-measuring system for diesel locomotive hydraulic transmission testing. Findings. The available equipment of the locomotive hydraulic transmission test-bench allowed for design of the optical type speed sensor based on the existing sensor D-2MMU-2. The factory testing with the use of a sensor prototype resulted in determination of the required and sufficient sampling time for sensor operating microcontroller. Originality. The available equipment of the locomotive hydraulic transmission testbench allowed for design of the optical type speed sensor based on the existing sensor D-2MMU-2. We developed the operation algorithms for the microcontroller that processes the signals from this sensor. The sensor was factorytested. According to the data sample obtained during the tests, we showed the possibility of reducing the sensor information retrieval frequency. Practical value. The designed sensor significantly reduces the cost of development of the diesel locomotive hydraulic transmission test-bench, besides it can be used when developing similar hydraulic transmission test-benches of other wheeled vehicles and the like. The designed sensor has a greater accuracy than that of D-2-2MMU and considerably lower production cost in comparison with current tachometer sensors. The measurement results are input data to perform further studies in order to determine the technical condition of UGP750-1200 hydraulic transmission during the factory post-repair testing.

Keywords: tachometer sensor; D-2MMU-2; hydraulic transmission; hydraulic transmission test; test-bench; data-measuring system

\section{Introduction}

Today in Ukraine, the hydraulic transmission is tested using the outdated test-benches designed in Soviet times, in particular at the repair plants of diesel locomotives and military equipment with hydraulic transmission. Also, there is no standardization of the production of these test-benches.

As part of the work for improvement and modernization of the existing hydraulic transmission test-bench at DZRT «Promteplovoz» plant it was revealed that the installed thereon analogue control devices are out-of-date. In the first stage of devel- opment in accordance with the plant test program the most necessary and critical 13 process parameters were selected. Information about which received from the sensors is processed by the microcontroller and PC [13].

Information about the rotation frequency of the drive motor, the generator, the turbine shaft is measured using D-2MMU-2 tachometer sensors [8], which transmit the pre-processed analogue signal to a special converter and then to ATMEL microcontroller for its further processing and transmission by USB 2.0 interface to the computer [13]. 
D-2MMU-2 sensor is nothing but an alternator, which has a critical flaw - at relatively low speeds (established experimentally at about $80 \mathrm{~min}^{-1}$ ) the voltage amplitude produced by the alternator is not sufficient for the normal error-free measurements (at speeds of about $60 \mathrm{~min}^{-1}$, the amplitude is about $1 \mathrm{~V}$, and at $2000 \mathrm{~min}^{-1}-40 \mathrm{~V}$ ). It is clear that at very low speeds the amplitude will be several tens of millivolts. To measure such a low voltage in the plant conditions is practically impossible, since, firstly, long communication lines from the testbench to the measuring equipment may have low voltage blanking and, secondly, at the plant there is a large number of different sources of electromagnetic interference, which may be laid on communication lines and erroneously recorded as the beginning of rotary motion on the test-bench.

It was proposed to use an incremental encoder $[2,4,5,10,12]$ XCC 1506PS [11] with excess precision - 2500 PPR) instead of tachometer generators. The tests showed its high accuracy and reliability in the measuring range of both fairly low speeds (0 to $80 \mathrm{~min}^{-1}$ ) and high ones (up to 2000 $\left.\mathrm{min}^{-1}\right)$. But the major drawback of this device is the difficulty of its mounting on the test-bench and the price that is high enough.

\section{Purpose}

As an alternative solution, it was proposed to make an in-house optical type sensor based on D-2-2MMU sensor housing. This solution has three important priorities: low price, ability to measure low speeds $\left(0\right.$ to $\left.80 \mathrm{~min}^{-1}\right)$, and possibility of installation inside the D-2MMU-2 sensor housing (or other tachometer-generators of the series) that does not require mechanical upgrading of the test-bench (which was required for using XCC $1506 \mathrm{PS}$ encoder). It is also essential that the developed device may apply a minor modification of the microcontroller control program, set up to process the signals from D-2MMU-2 sensor transmitter.

At the initial stage of development, the sensor consisted of a shaft, on which there was a handmade plastic disc with teeth, and infrared optical coupler EE-SX1041 [9]. The tests have shown that hand-made teeth did not allow high accuracy measurements. Therefore, to ensure greater accuracy a 10-tooth acrylic disc was manufactured on industrial equipment by laser technique. The drawing of the disk is shown in Fig. 1.

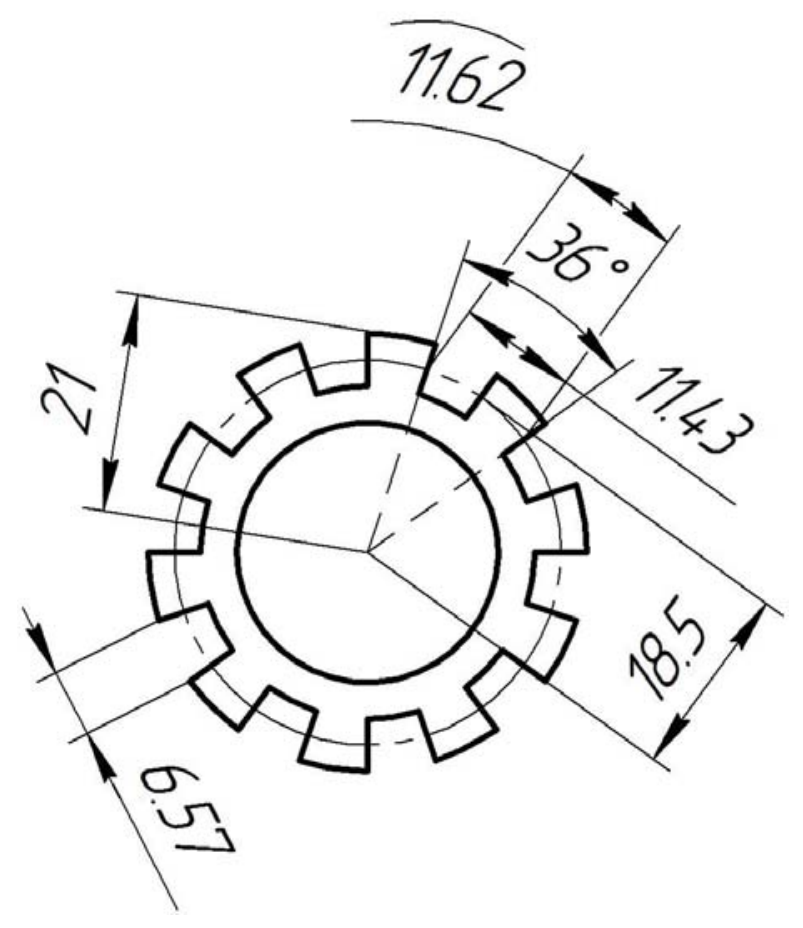

Fig. 1. Disc drawing

Connection circuit of the sensor optical coupler allows virtually eliminating the effect of the pulse rise and decay time (a few microseconds). Therefore, their effect on the measurement system performance can be omitted during theoretical calculation of the measured values of rotation speed.

The first thing to bear in mind is that the measuring disk production technique is not perfect and variations in tooth size are inevitable. Thereafter, you need to perform calculations for dependence of the instrumental error (arc length, as shown in Fig. 1) on the rotation speed. The first version of the rotation speed measurement algorithm, embedded in the microcontroller, fixes the appearance of the rising edge of each new impulse signal and as a result performs the measurement of the signal cycle time. Simplified diagram of the microcontroller operation algorithm is shown in Fig. 2. The algorithm begins with timer/ counter setting, reset of the flags required for operation and zeroing of variables, UART setting (necessary for data transmission to a computer) and interrupt enabling setting. The following step is an endless loop in which the end of the measurement is checked. For occurrence of the measurement end event the following two events must occur, as shown in Fig. 3. 


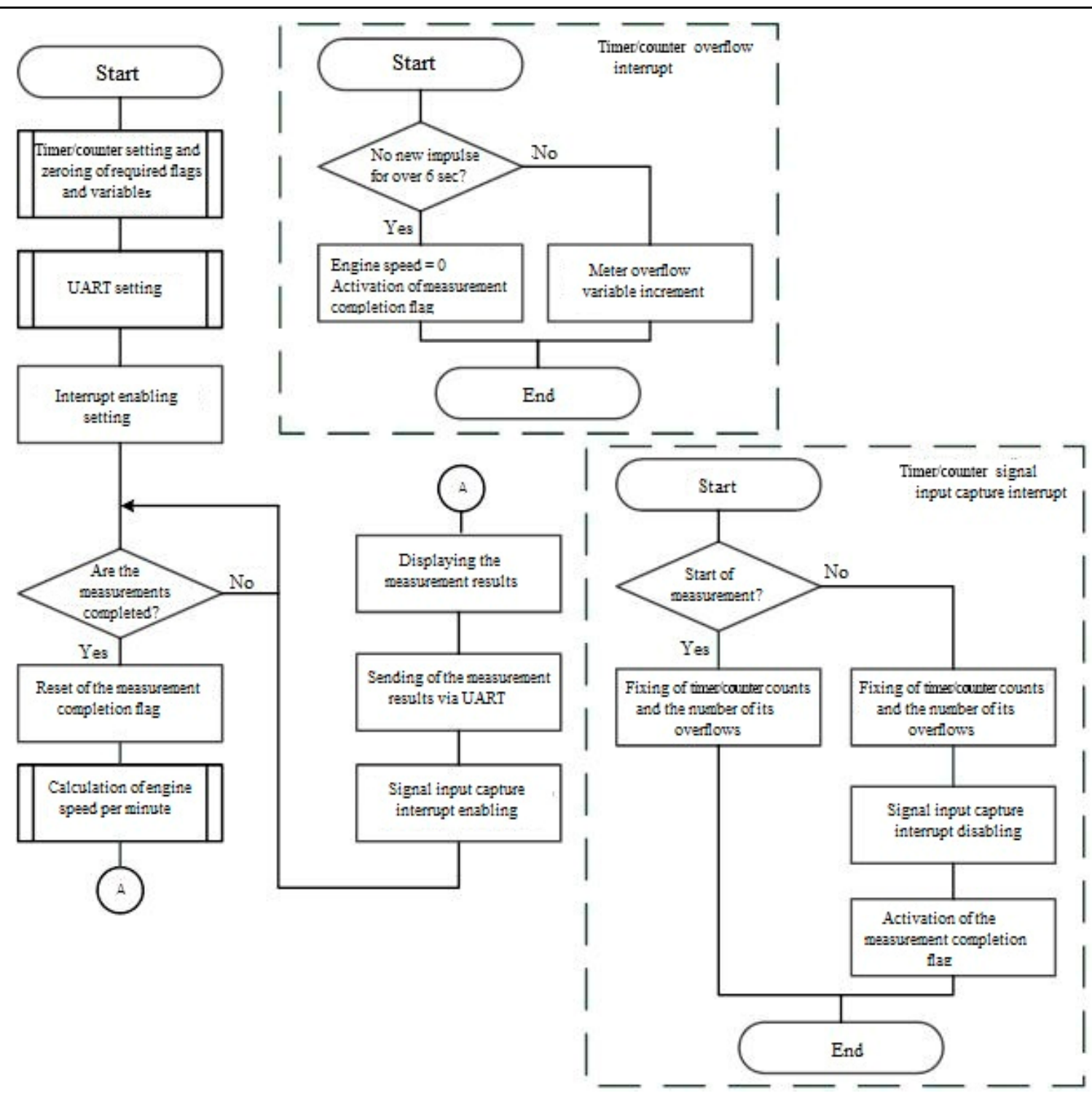

Fig. 2 Simplified diagram of the microcontroller operation algorithm

Terminal measurement edge 1

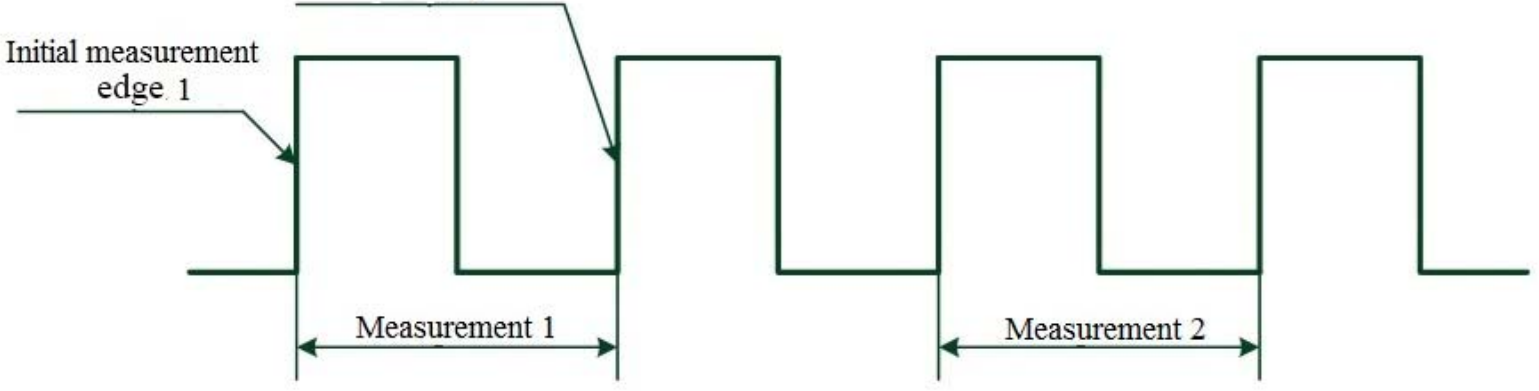

Fig. 3 Principle sensor signal processing 
Upon receiving the initial edge of the microcontroller input capture signal, the timer/counter of signal input capture interrupts, as shown in Fig. 4.

The clock interrupt handler fixes the counts of the timer/ counter and the number of its overflow interrupts in special variables. In case of interrupt of the measurement final edge capture, the system also fixes the counts of the timer/ counter and the number of its overflow interrupts in special variables, and thereafter the signal input capture interrupts are disabled, the measurement completion flag is set.

The activated measurement completion flag notifies the main microcontroller program about the end of the measurement. Thereafter the following is performed: reset of the measurement completion flag, subroutine of engine speed calculation per $\min ^{-1}$, displaying the measurement results and sending them via UART. At the end the system allows for signal input capture interrupts and therefore for a new measurement, as well as puts the microcontroller on standby at the end of the measurement.

The timer/counter overflow interrupt program serves to count the number of timer/counter overflows in the special variable, and to initiate the end of the measurement with zero result in the absence of a signal at the signal capture input for more than $6 \mathrm{sec}$.

The engine speed is calculated by the following formula:

$$
\begin{array}{r}
\omega=\frac{1}{\left(\frac{f_{c p u}}{k}\right)^{-1}\left(\left(65535 f_{e}+T_{e}\right)-\left(65535 f_{b}+T_{b}\right)\right)} \times \\
\times 60\left[\mathrm{~min}^{-1}\right],
\end{array}
$$

where $\omega$ - rotation speed $\left[\mathrm{min}^{-1}\right] ; f_{\mathrm{cpu}}-$ clock generator frequency $[\mathrm{Hz}] ; k$ - timer/counter frequency divider; $f_{e}, f_{b}$ - the number of timer/counter overflows at the end and the beginning of the measurements, respectively; $T_{e}, T_{b}-$ timer/counter counts at the end and the beginning of the measurements, respectively.

We performed the calculation of the delay effects, coupled in by the algorithm when performing the measurements. It was determined that the execution of all assembler commands involved in the measurements makes $\sim 6.75$ microseconds. This error $\varepsilon_{\Delta}$ can be neglected, since, at a rotation speed of $1500 \mathrm{~min}^{-1}$ the cycle of the measured signal is $40 \mathrm{~ms}$.

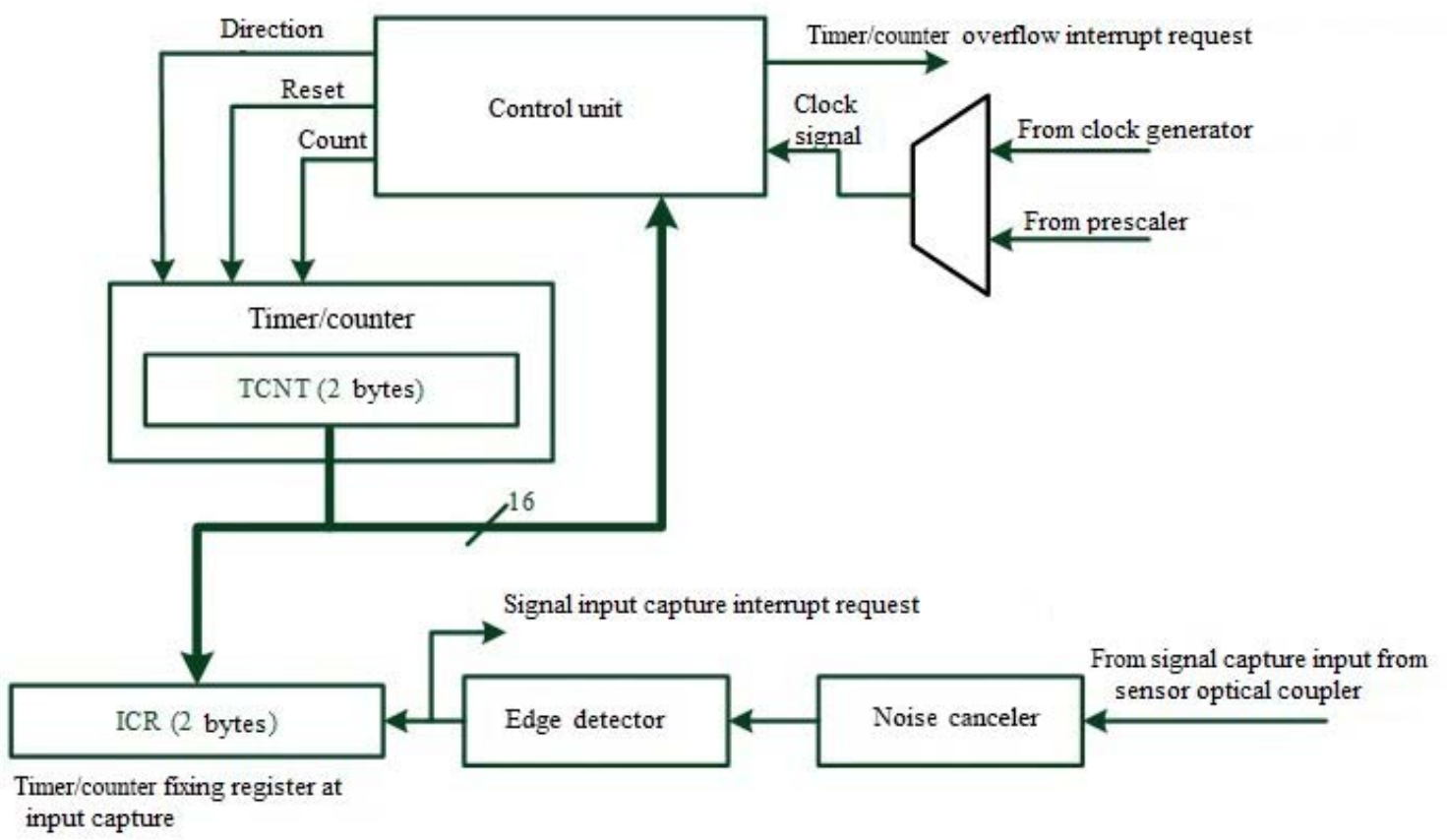

Fig. 4. Simplified block diagram of timer/counter 
To simplify the calculations it was taken to neglect the backlash of the shaft where the disk is mounted.

\section{Methodology}

Rotation speed is calculated by the following formula:

$$
\omega=\frac{1}{T} \cdot 60\left[\mathrm{~min}^{-1}\right]
$$

where $\omega$ - rotation speed $\left[\mathrm{min}^{-1}\right] ; T$ - rotation pe$\operatorname{riod}[\mathrm{sec}]$.

Since the disk is divided into 10 sectors with arc length $L$, the rotation speed calculation will be as follows:

$$
\omega_{\text {theor }}=\frac{L}{2 \pi R \tau} \cdot 60\left[\mathrm{~min}^{-1}\right] \text {, }
$$

where $\omega_{\text {theor }}-$ theoretical rotation speed $\left[\mathrm{min}^{-1}\right] ; L$ - arc length [mm]; $R$ - distance from the disc center to the tooth height middle [mm]; $\tau$ - passage time of optical coupler infrared beam of the arc $L$ (signal cycle) [sec].

The only variable which will affect the calculation of the theoretical speed will be the arc length, which may differ from the theoretical one, due to a manufacturing error of the toothed disc.

Let us assume that the actual length of the arc is equal to $L^{*}$, then substituting $L^{*}$ in (1) we obtain the actual rotation speed:

$$
\omega_{a c t}=\frac{L^{*}}{2 \pi R \tau} \cdot 60\left[\mathrm{~min}^{-1}\right],
$$

Absolute error will be as follows:

$$
\Delta=\omega_{\text {theor }}-\omega_{\text {act }}\left[\mathrm{min}^{-1}\right],
$$

Substituting (1) and (2) in (3) we obtain:

$$
\Delta=\omega_{a c t} \frac{\Delta_{L}}{L+\Delta_{L}}\left[\min ^{-1}\right]
$$

where $\Delta_{\mathrm{L}}$ - difference between the actual and theoretical arc length $L[\mathrm{~mm}] ; \Delta$ - absolute error [sex].

The relative error on the basis of (4) will have the following form:

$$
\varepsilon=\frac{\Delta_{L}}{L+\Delta_{L}} \approx \frac{\Delta_{L}}{L} .
$$

We should perform the following calculation with such assumptions: error in the arc length is \pm 2 $\mathrm{mm}$ with $0.1 \mathrm{~mm}$ spacing. Fig. 5 shows the graph of rotation speed relative error on the actual tooth size production error (the actual arc length $L$ on tooth center).

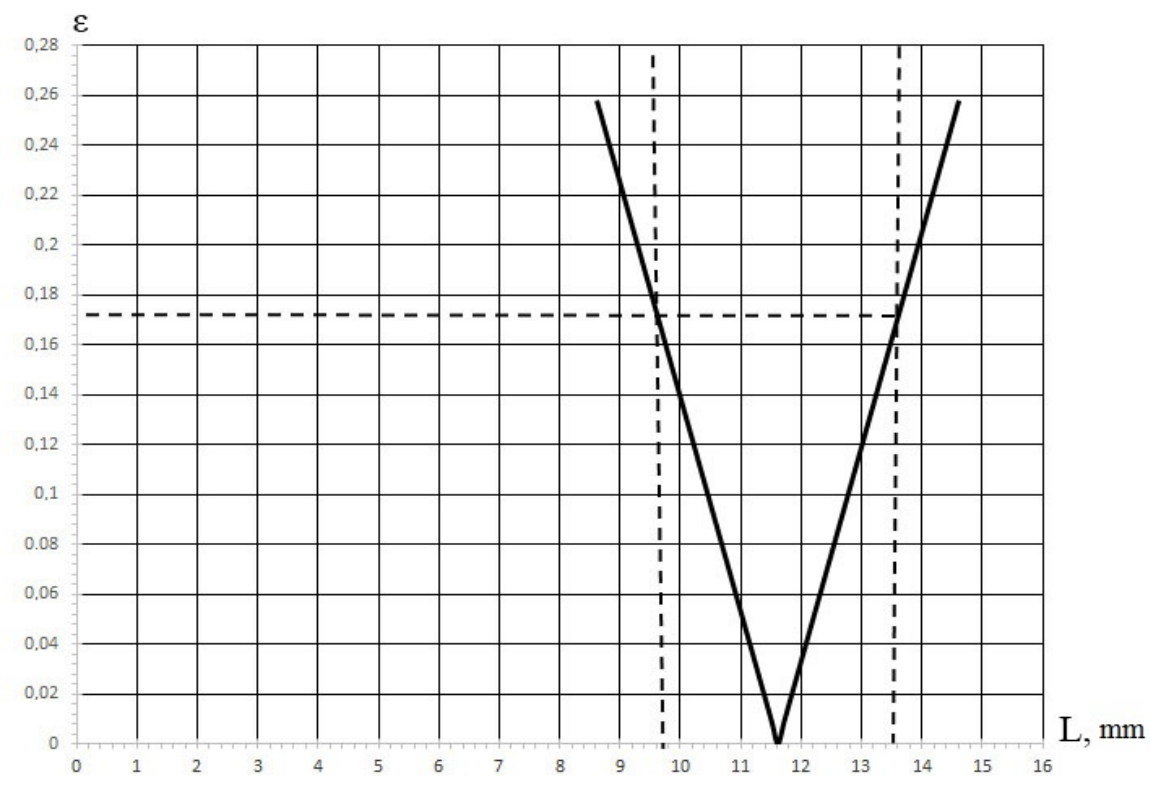

Fig. 5. Graph of rotation speed relative error on the actual tooth size production error 
The graph in Fig. 5 shows that the deviation of $L$ from the theoretical size by $\pm 2 \mathrm{~mm}$ the relative error will be no more than $17 \%$. This is the variance between actual and theoretical length $\mathrm{L}$ that is provided with the disc production technique. Based on the obtained data we can state that the use of the measurement algorithm (see Fig. 2) at the maximum possible rotation speed of $1500 \mathrm{~min}^{-1}$ may result in the absolute error of $\sim \pm 255 \mathrm{~min}^{-1}$.

To reduce the influence of the error discussed above, it was decided to modify the measurement algorithm by taking the mean of 10 measurements (i.e. to obtain an approximate value of rotation speed per one revolution of the disk, rather than per passage of the $\operatorname{arc} L$ ).

Further modification of the algorithm is as follows: upon occurrence of the first impulse from the sensor the timer/counter should react to the capture input as previously. And upon occurrence of the next impulse edge it must not finish counting the signal cycle time period but continue counting as long as the required number of impulses is reached, and only then stop and perform the speed calculation.

It is clear that the optimal number of impulses at which the resulting speed sample is not distorted and does not lose representativeness is unknown.

To determine the necessary and sufficient number of impulses it is necessary to take into account that the uniform rotation will not give the required information. Therefore we used the uniform acceleration data obtained from actual factory tests during the algorithm with counting of the sum of ten signal cycles (although such data contain the additional error $\varepsilon_{\Delta_{i}}$, it is not critical for the subsequent calculations).

For the particular case the uniform acceleration is represented by the following formula:

$$
\vec{a}=\frac{\partial \vec{v}}{\partial t}=\frac{\Delta v}{\Delta t}\left[\mathrm{~min}^{-1} / \mathrm{sec}^{2}\right]
$$

where $\vec{a}$ - acceleration $\left[\mathrm{min}^{-1} / \mathrm{sec}^{2}\right] ; \Delta v$ - rotation speed gain over time $\Delta t$ [sec].

The non-repeated sampling will be considered $[1,6,7]$ (it is assumed that the uniform acceleration does not give the same results in the sample of rotation speeds, whose general population will be considered).
In this case, the variance is calculated by the formula:

$$
\sigma=\sqrt{\frac{\sum_{i=1}^{n}\left(\omega_{i}-\bar{\omega}\right)}{n-1}},
$$

where $\sigma$ - variance; $\omega_{i}-i$-dimension of rotation speed $\left[\min ^{-1}\right] ; \bar{\omega}$ - arithmetic mean of $n$-dimension sample rotation speed $\left[\mathrm{min}^{-1}\right] ; n$ - sample size of considered accelerations (general population).

The mean square error $\mu$ of the sample using non-repeated sampling is as follows [1]:

$$
\mu=\sqrt{\frac{\sigma^{2}}{n}\left(1-\frac{n^{*}}{n}\right)},
$$

where $n^{*}-$ size of the necessary and sufficient sample from the general population $\mathrm{n}$.

In this case, the absolute error will be as follows:

$$
\Delta \omega= \pm t \cdot \mu\left[\mathrm{min}^{-1}\right],
$$

where $\Delta \omega-$ absolute error; $\mathrm{t}-$ Student's coefficient.

Student's coefficient is in the table from [6] and for the confidence level $\alpha=95 \%$ is 1.98 .

Substituting (5) into (6) and performing the necessary transformations we can get the formula for calculating the required sample size $n^{*}$ of the population $n$ :

$$
n^{*}=\frac{t^{2} \sigma^{2} n}{\Delta \omega^{2} n+t^{2} \sigma^{2}}
$$

For the general population equal to 1657 samples the calculations results are presented in Fig. 6.

Calculation of absolute error of the general population is conducted without regard to the selection of the sample $\mathrm{n}^{*}$ by the formulas:

$$
\mu^{*}=\sqrt{\frac{1}{n(n-1)} \sum_{i=1}^{n}\left(\omega_{i}-\bar{\omega}\right)^{2}},
$$

where $\mu^{*}-$ mean square error.

$$
\Delta \omega^{*}= \pm \mu^{*} \cdot t,
$$

where $\Delta \omega^{*}$ - absolute error. 


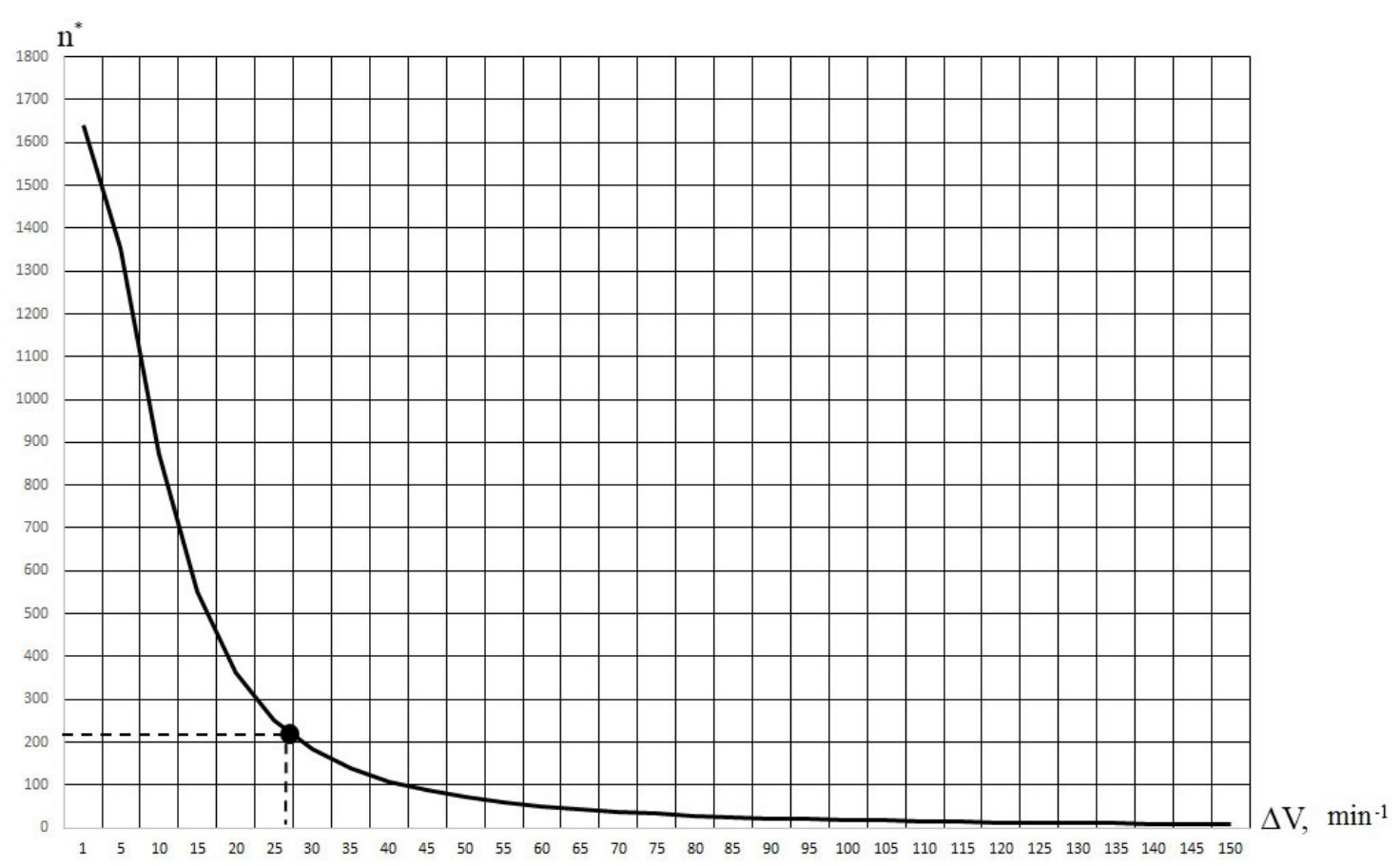

Fig. 6. Graph of rotation speed absolute error on the $\mathrm{n}^{*}$ sample size

Absolute error of the used general population (without regard to selection of sample $\mathrm{n}^{*}$ ) equals to $27.94 \mathrm{~min}^{-1}$. As seen in Figure 6 in this case $n^{*} \approx 208$. On this basis it can be affirmed that the sample $\mathrm{n}^{*}$ is representative and does not distort the general population $\mathrm{n}$, when sampling only each 8 th count from $n(1657 / 208 \approx 8)$. Similar results were obtained when processing other samples.

Variations of instrumental and methodical errors, which may be due to missing counts, require further research.

\section{Findings}

The available equipment of the locomotive hydraulic transmission test-bench allowed for design of the optical type speed sensor based on the existing sensor D-2MMU-2. The factory testing with the use of a sensor prototype resulted in determination of the required and sufficient sampling time for sensor operating microcontroller, which allowed making changes to the measurement algorithm.

\section{Originality and practical value}

The available equipment of the locomotive hydraulic transmission test-bench allowed for design of the optical type speed sensor based on the exist- ing sensor D-2MMU-2. The operation algorithms for the microcontroller that processes the signals from this sensor were developed. The sensor was factory-tested. According to the data sample obtained during the tests, we showed the possibility of reducing the sensor information retrieval frequency. The designed sensor significantly reduces the cost of development of the diesel locomotive hydraulic transmission test-bench, besides it can be used when developing similar hydraulic transmission test-benches of other wheeled vehicles and the like. The designed sensor has a greater accuracy than that of D-2-2MMU and considerably lower production cost in comparison with current tachometer sensors. The measurement results are input data to perform further studies in order to determine the technical condition of UGP750-1200 hydraulic transmission during the factory postrepair testing.

\section{Conclusions}

The available equipment of the locomotive hydraulic transmission test-bench allowed for design of the optical type speed sensor based on the existing sensor D-2MMU-2. The paper considered possible sources of measurement error of the new sensor. The instrumental error introduced by sensor 
production techniques was calculated and it was found that the current sensor signal processing algorithm is not perfect and requires improvement. An improved algorithm was proposed. The factory tests of sensor allowed performing the necessary calculations of the required frequency for computer sampling of the sensor operating microcontroller for the purpose of correcting the rotation speed calculation algorithm.

\section{LIST OF REFERENCE LINKS}

1. Балинова, В. С. Статистика в вопросах и ответах : учеб. пособие. - Москва : ТК Велби : Издво Проспект, 2004. - 344 с.

2. Безгин, А. С. Применение инкрементального энкодера как датчика скорости в цифровых системах управления экскаваторного электропривода переменного тока / А. С. Безгин, Э. Л. Греков // Науч.-техн. вестн. Поволжья. 2013. - № 3. - С. 72-76.

3. Жуковицкий, И. В. Использование микроконтроллеров в стенде испытания гидравлических передач тепловоза / И. В. Жуковицкий, И. А. Клюшник // Безпека та електромагнітна сумісність на залізничному транспорті : тези VII Міжнар. наук.-практ. конф. (16.0219.02.2016), с. Розлуч / Дніпропетр. нац. ун-т залізн. трансп. ім. акад. В. Лазаряна. - Дніпропетровськ, 2016. - С. 33.

4. Информационно-управляющая система активного аэростатического подшипника на базе фотоэлектрического преобразователя комбинированного типа [Electronic resource] / А. В. Кирьянов, В. В. Чуканов, В. П. Кирьянов, С. В. Перебейнос // Интерэкспо Гео-Сибирь. 2013. - Вып. 1, т. 5. - 8 с. - Available at: http://cyberleninka.ru/article/n/informatsionnoupravlyayuschaya-sistema-aktivnogoaerostaticheskogo-podshipnika-na-bazefotoelektricheskogo-preobrazovatelya. Title from the screen. - Accessed : 12.09.2016.

5. Клюшник, I. А. Використання інформаційних технологій для вимірювання частоти обертання на стенді випробування гідравлічних передач тепловозів / I. А. Клюшник // Інформ. технології в моделюванні : матер. всеукр. наук.-практ. конф. студентів, аспірантів та молодих вчених (24.03-25.03.2016) / Миколаїв. нац. ун-т ім. В. О. Сухомлинського. - Миколаїв, 2016. C. $82-83$.

6. Руденко, В. М. Математична статистика : навч. посібник / В. М. Руденко. - Київ : Центр учбової літ-ри, 2012. - 303 с.
7. Степнов, М. Н. Статистические методы обработки результатов механических испытаний : справочник. - Москва : Машиностроение, 1985. -232 c.

8. Тахометры магнитоиндукционные дистанционные ТМи [Electronic resource] // OOO «Caранские приборы». - 2016. - Available at: http://sibspz.ru/pribory-dlya-izmereniyaparametrov-dvizheniya-takhometry/takhometrymagnitoinduktsionnye-distantsionnye-tmi. - Title from the screen. - Accessed : 2.07.2016.

9. EE-SX1041. Photomicrosensor (Transmissive) [Electronic resource] // OMRON Corporation. 2016. - Available at: https://www.omron.com/ecb/products/photo/34/ee_sx1041.html. - Title from the screen. - Accessed : 2.07.2016.

10. Improved PSO algorithm for improving the subdivision accuracy of photoelectric rotary encoder / G. Xu, W. Qiuhua, Y. Shouwang [et al.] // Infrared and Laser Engineering. - 2013. - T. 42, № 6. C. 320-323.

11. Information-measuring Test System of Diesel Locomotive Hydraulic Transmissions / I. V. Zhukovytskyy, I. A. Kliushnyk, O. B. Ochkasov, R. O. Korenyuk // Наука та прогрес транспорту. - 2015. - № 5 (59). - C. 53-65. doi: 10.15802/stp2015/53159.

12. Opto-electronic rotary encoders OsiSense XCC. Catalogue [Electronic resource] // Schneider Electric. - 2016. - Available at: http://katalog.schneiderelectric.cz/dsmapp/data/pdf/cz/TL3/XCC Rotary OsiSense.pdf. - Title from the screen. - Accessed : 2.07.2016.

13. Zheng, D. A capacitive rotary encoder based on quadrature modulation and demodulation / D. Zheng, S. Zhang, S. Wang // IEEE Transactions on Instrumentation and Measurement. 2015. - Vol. 64. - Iss. 1. - P. 143-153. doi: 10.1109/TIM.2014.2328456. 
I. В. ЖУКОВИЦЬКИЙ ${ }^{*}$, I. А. КЛЮШНИК ${ }^{2 *}$

\begin{abstract}
${ }^{1 *}$ Каф. «Електронні обчислювальні машини», Дніпропетровський національний університет залізничного транспорту імені академіка В. Лазаряна, вул. Лазаряна, 2, Дніпро, Україна, 49010, тел. +38 (056) 37315 89, ел. пошта ivzhuk@mail.ru, ORCID 0000-0002-3491-5976

${ }^{2 *}$ Каф. «Електронні обчислювальні машини», Дніпропетровський національний університет залізничного транспорту імені академіка В. Лазаряна, вул. Лазаряна, 2, Дніпро, Україна, 49010, тел. +38 (056) 3731589 , ел. пошта klugran@i.ua, ORCID 0000-0001-9939-0755
\end{abstract}

\title{
ВИКОРИСТАННЯ МІКРОКОНТРОЛЕРА ДЛЯ ВИМІРЮВАННЯ ЧАСТОТИ ОБЕРТАННЯ ВАЛА ГІДРАВЛІЧНОЇ ПЕРЕДАЧІ ТЕПЛОВОЗА
}

Мета. Стаття передбачає розгляд процесу розробки та вдосконалення засобів збору тахометричних даних інформаційно-вимірювальної системи випробування гідравлічних передач тепловозів. Це дасть можливість отримання вихідних даних для проведення подальших досліджень із визначення технічного стану гідравлічних передач тепловозів. Передбачається знайти вирішення завдання розробки і удосконалення засобів вимірювання тахометричних даних раніше створеної інформаційно-вимірювальної системи випробувань гідравлічних передач тепловозів. При цьому відштовхуватись потрібно, в першу чергу, від можливості модифікації вже існуючого стенду випробувань гідравлічних передач тепловозів на Дніпропетровському заводі по ремонту тепловозів «Промтепловоз». Методика. У роботі дослідниками була запропонована методика модифікації існуючого тахометричного датчика мікропроцесорної автоматизованої системи стендових випробувань гідравлічних передач тепловозів в умовах тепловозоремонтного заводу. Вона діє шляхом обгрунтування вибору необхідного способу вимірювання тахометричного датчика, а також застосування необхідних апаратних та програмних засобів для реалізації поставленої мети з можливістю інтеграції в інформаційно-вимірювальну систему випробувань гідравлічних передач тепловозів. Результати. Авторами спроектований і виготовлений діючий прототип датчика частоти обертання оптичного типу на основі вже існуючого датчика Д-2ММУ-2. Після заводських випробувань із застосуванням прототипу датчика був встановлений необхідний і достатній час опитування керуючого мікроконтролера датчика. Наукова новизна. На наявному обладнання стенду випробувань гідравлічних передач тепловозів був спроектований датчик частоти обертання оптичного типу на основі вже існуючого датчика Д-2ММУ-2. Були розроблені алгоритми роботи мікроконтролера, який займається обробкою сигналів від цього датчика. Проведені заводські випробування датчика. За вибіркою даних, отриманих при випробуваннях, показана можливість зменшення частоти знімання інформації з датчика. Практична значимість. Удосконалений датчик істотно здешевлює виготовлення стенда випробувань гідравлічних передач тепловозів, а також може застосовуватися при розробці аналогічних стендів випробувань гідравлічних передач іншої колісної техніки і т. п. механізмів. Розроблений датчик має більшу точність у порівнянні з Д-2ММУ-2 і значно меншу, в порівнянні з сучасними тахометричними датчиками, ціну виготовлення. Результати вимірювань є вихідними даними для виконання подальших досліджень із метою визначення технічного стану гідравлічної передачі УГП750-1200 під час заводських післяремонтних випробувань.

Ключові слова: тахометричний датчик; Д-2ММУ-2; гідравлічна передача; випробування гідропередач; випробувальний стенд; інформаційно-вимірювальна система

\section{и. В. ЖУКОВИцКиЙ ${ }^{1 *}$, И. А. КЛЮшник ${ }^{2 *}$}

\footnotetext{
${ }^{1 *}$ Каф. «Электронные вычислительные машины», Днепропетровский национальный университет железнодорожного транспорта имени академика В. Лазаряна, ул. Лазаряна, 2, Днипро, Украина, 49010, тел. +38 (056) 3731589 , эл. почта ivzhuk@mail.ru, ORCID 0000-0002-3491-5976

${ }^{2 *}$ Каф. «Электронные вычислительные машины», Днепропетровский национальный университет железнодорожного транспорта имени академика В. Лазаряна, ул. Лазаряна, 2, Днипро, Украина, 49010, тел. +38 (056) 3731589 , эл. почта klugran@i.ua, ORCID 0000-0001-9939-0755
} 


\section{ИСПОЛЬЗОВАНИЕ МИКРОКОНТРОЛЛЕРА ДЛЯ ИЗМЕРЕНИЯ ЧАСТОТЫ ВРАЩЕНИЯ ВАЛА ГИДРАВЛИЧЕСКОЙ ПЕРЕДАЧИ ТЕПЛОВОЗА}

Цель. Статья предусматривает рассмотрение процесса разработки и усовершенствования средств сбора тахометрических данных информационно-измерительной системы испытания гидравлических передач тепловозов. Это даст возможность получения исходных данных для проведения дальнейших исследований по определению технического состояния гидравлических передач тепловозов. Предполагается найти решение задачи разработки и усовершенствования средств измерения тахометрических данных ранее созданной информационно-измерительной системы испытаний гидравлических передач тепловозов. При этом отталкиваться необходимо, в первую очередь, от возможности модификации уже существующего стенда испытаний гидравлических передач тепловозов на Днепропетровском заводе по ремонту тепловозов «Промтепловоз». Методика. В работе исследователями была предложена методика модификации существующего тахометрического датчика микропроцессорной автоматизированной системы стендовых испытаний гидравлических передач тепловозов в условиях тепловозоремонтного завода. Она действует путем обоснования выбора необходимого способа измерения тахометрического датчика, а также применения необходимых аппаратных и программных средств для реализации поставленной цели с возможностью интеграции в информационноизмерительную систему испытаний гидравлических передач тепловозов. Результаты. Авторами спроектирован и изготовлен действующий прототип датчика частоты вращения оптического типа на основе уже существующего датчика Д-2ММУ-2. После заводских испытаний с применением прототипа датчика было установлено необходимое и достаточное время опроса управляющего микроконтроллера датчика. Научная новизна. На имеющемся оборудовании стенда испытаний гидравлических передач тепловозов был спроектирован датчик частоты вращения оптического типа на основе уже существующего датчика Д-2ММУ-2. Были разработаны алгоритмы работы микроконтроллера, обрабатывающего сигналы от этого датчика. Проведены заводские испытания датчика. По выборке данных, полученных при испытаниях, показана возможность уменьшения частоты съема информации с датчика. Практическая значимость. Усовершенствованный датчик существенно удешевляет изготовление стенда испытаний гидравлических передач тепловозов, а также может применяться при разработке аналогичных стендов испытаний гидравлических передач другой колесной техники и т. п. механизмов. Разработанный датчик имеет большую точность по сравнению с Д-2ММУ-2 и значительно меньшую, в сравнении с современными тахометрическими датчиками, цену изготовления. Результаты измерений являются исходными данными для выполнения дальнейших исследований с целью определения технического состояния гидравлической передачи УГП750-1200 во время заводских послеремонтных испытаний.

Ключевые слова: тахометрический датчик; Д-2ММУ-2; гидравлическая передача; испытания гидропередач; испытательный стенд; информационно-измерительная система

\section{REFERENCES}

1. Balinova B.C. Statistika v voprosakh i otvetakh [Statistics in questions and answers]. Moscow, TK Velbi, Prospekt Publ., 2004. 344 p.

2. Bezgin A.S., Grekov E.L. Primeneniye inkrementalnogo enkodera kak datchika skorosti v tsifrovykh sistemakh upravleniya ekskavatornogo elektroprivoda peremennogo toka [Application of incremental encoder as a speed sensor in digital control systems of excavating AC drive]. Nauchno-tekhnicheskiy vestnik PovolzhyaScientific and Technical Bulletin of Povolzhe, 2013, no. 3, pp. 72-76.

3. Zhukovitskiy I.V., Kliushnyk I.A. Ispolzovaniey mikrokontrollerov v stende ispytaniya gidravlicheskikh peredach teplovoza [Using of microcontrollers in the test stand of hydraulic transmission in a locomotive]. Tezy VII Mizhnarodnoi naukovo-praktychnoi konferentsii «Bezpeka ta elektromahnitna sumisnist na zaliznychnomu transporti (16.02-19.02.2016)» [Proc. of VII Intern. Sci. and Pract. Conference «Safety and electromagnetic compatibility at rail transport (16.02-19.02.2016)»]. Dnipropetrovsk, 2016, p. 33.

4. Kiryanov A.V., Chukanov V.V., Kiryanov V.P., Perebeynos S.V. Informatsionno-upravlyayushchaya sistema aktivnogo aerostaticheskogo podshipnika na baze fotoelektricheskogo preobrazovatelya kombinirovannogo tipa (Information and control system of active air bearings on the basis of the photoelectric converter of the combined type). Interekspo Geo-Sibir - Interekspo Geo-Siberia, 2013, issue 1, vol. 5. 8 p. Available at: http://cyberleninka.ru/article/n/informatsionno-upravlyayuschaya-sistema-aktivnogo-aerostaticheskogopodshipnika-na-baze-fotoelektricheskogo-preobrazovatelya (Accessed 12 September 2016). 
5. Kliushnyk I.A. Vykorystannia informatsiinykh tekhnolohii dlia vymiriuvannia chastoty obertannia na stendi vyprobuvannia hidravlichnykh peredach teplovoziv [Information technology usage for measuring the rotary vellocity at test stand of hydraulic transmissions in locomotives]. Materialy vseukrainskoi naukovopraktychnoi konferentsii studentiv, aspirantiv ta molodykh vchenykh: "Informatsiino-tekhnolohii v modeliuvanni (24.03-25.03.2016)» [Proc. of All Ukrainian Sci. and Practical Conf. for students, PG students, young scientists «Information technologies in simulation (24.03-25.03.2016)»]. Mykolaiv, 2016, pp. 82-83.

6. Rudenko V.M. Matematychna statystyka [Mathematical Statistics]. Kyiv, Tsentr uchbovoi literatury Publ., 2012. $303 \mathrm{p}$.

7. Stepnov M.N. Statisticheskiye metody obrabotki rezultatov mekhanicheskikh ispytaniy: spravochnik [Statistical methods for processing the results of mechanical tests: handbook]. Moscow, Mashinostroeniye Publ., 1985. $232 \mathrm{p}$.

8. Takhometry magnitoinduktsionnyye distantsionnyye TMi. OOO «Saranskiye pribory» (Tachometers of magnetic remote TMI. LLC «Saransk equipment»). 2016. Available at: http://sibspz.ru/pribory-dlya-izmereniyaparametrov-dvizheniya-takhometry/takhometry-magnitoinduktsionnye-distantsionnye-tmi (Accessed 2 July 2016).

9. EE-SX1041 Photomicrosensor (Transmissive). OMRON Corporation. 2016. Available at: https://www.omron.com/ecb/products/photo/34/ee_sx1041.html (Accessed 2 July 2016).

10. Xu G., Qiuhua W., Shouwang Y., Wei C., Changhai Z. Improved PSO algorithm for improving the subdivision accuracy of photoelectric rotary encoder. Infrared and Laser Engineering, 2013, vol. 42, no. 6, pp. 320323.

11. Zhukovytskyy I.V., Kliushnyk I.A., Ochkasov O.B., Korenyuk R.O. Information-measuring Test System of Diesel Locomotive Hydraulic Transmissions. Nauka ta prohres transportu - Science and Transport Progress, 2015, no. 5 (59), pp. 53-65. doi: 10.15802/stp2015/53159.

12. Opto-electronic rotary encoders OsiSense XCC. Catalogue. Schneider Electric. 2016. Available at: http://katalog.schneider-electric.cz/dsmapp/data/pdf/cz/TL3/XCC_Rotary_OsiSense.pdf (Accessed 2 July 2016).

13. Zheng D., Zhang S., Wang S., Zheng D. A capacitive rotary encoder based on quadrature modulation and demodulation. IEEE Transactions on Instrumentation and Measurement, 2015, vol. 64, issue 1, pp. 143-153. doi: 10.1109/TIM.2014.2328456.

Prof. V. V. Skalozub, D. Sc. (Tech.) (Ukraine); Prof. A. I. Mikhalev, D. Sc. (Tech.) (Ukraine) recommended this article to be published

Accessed: June 25, 2016

Received: Oct. 07, 2016 